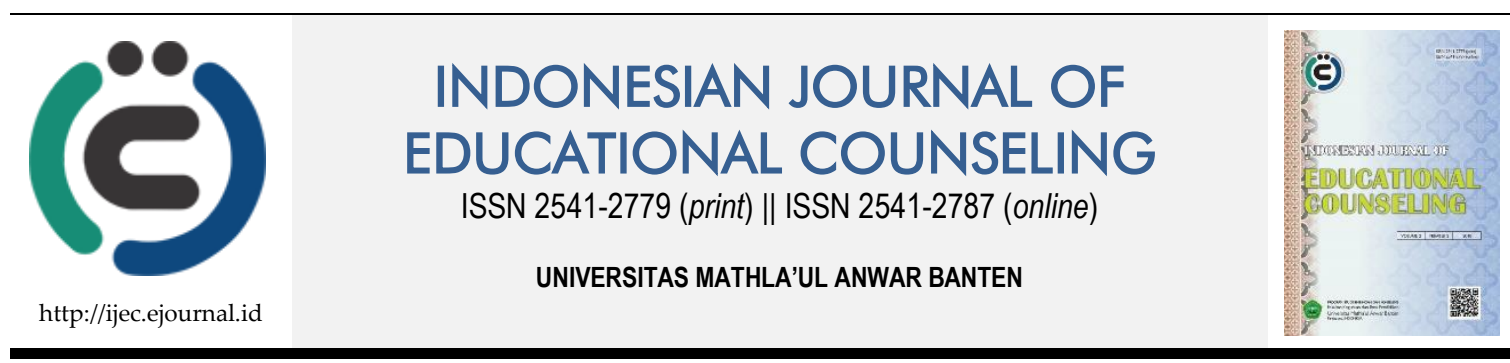

Research Based Article

\title{
Profil Kematangan Karier Mahasiswa STAI Siliwangi Bandung
}

\author{
Ahmad Rifqy Ash Shiddiqy ${ }^{1}$ \\ 1 Universitas Pendidikan Indonesia
}

\begin{tabular}{|c|c|}
\hline ARTICLE INFO & ABSTRACT \\
\hline $\begin{array}{l}\text { Article History: } \\
\text { Received 06.04.2018 } \\
\text { Received in revised } \\
\text { form } 28.05 .2018 \\
\text { Accepted } 02.07 .2018 \\
\text { Available online } \\
21.07 .2018\end{array}$ & $\begin{array}{l}\text { This study is driven by the tendency of guidance and counseling services at } \\
\text { universities, especially in STAI Siliwangi Bandung by students to establish their } \\
\text { future career maturity, nevertheless, the services obtained do not meet their } \\
\text { expectations. Considering career guidance for students, especially student } \\
\text { career maturity is left alone, passes, and runs by itself. Then students will } \\
\text { experience confusion and unpreparedness in facing the next career demands. } \\
\text { Students are the final status as learners before entering the world of work and } \\
\text { following career demands, so they need direction, career guidance to stimulate } \\
\text { the development and stabilization of their career orientation optimally } \\
\text { according to the level and characteristics typical of the progress as it goes } \\
\text { through. The purpose of this research is the formation of the maturity profile of } \\
\text { the student's career. This research uses the quantitative method. This research } \\
\text { produces (1) Maturity picture of Student Career (2) The effectiveness of career } \\
\text { counseling to strengthen the maturity of the student's career. The conclusion of } \\
\text { the research is the maturity of the student's career is in mature category, there } \\
\text { is no career guidance service to strengthen student career maturity in STAI } \\
\text { Siliwangi Bandung, based on the results of research can be formulated a model } \\
\text { of collaborative career guidance services to harden the maturity of STAI } \\
\text { Siliwangi Bandung student career. }\end{array}$ \\
\hline
\end{tabular}

Keywords: Career Guidance, Career Maturity, Student.

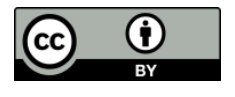

This is an open access article distributed under the terms of the Creative Commons Attribution 4.0 International License, which permits unrestricted use, distribution, and reproduction in any medium, provided the original work is properly cited. C 2018 Ahmad Rifqy Ash Shiddiqy.

\section{PENDAHULUAN}

Salah satu tugas perkembangan mahasiswa adalah mempersiapkan suatu karier. (Santrock, 2003, p. 87). Mahasiswa diharapkan mampu menentukan karier untuk ditekuni dikemudian hari dan mulai mempersiapkan diri, baik dalam hal pendidikan ataupun keterampilan yang relevan dengan karier yang dipilih. Pemilihan bidang pekerjaan berkaitan erat dengan penentuan program pendidikan, karena suatu bidang pekerjaan

${ }^{1}$ Corresponding author's address: Universitas Pendidikan Indonesia Kampus Cibiru; Jl. Pendidikan, Cibiru Wetan, Cileunyi, Kota Bandung, Jawa Barat 40625. Email: rifqy45@upi.edu. 
menuntut seseorang untuk menyelesaikan pendidikan dan pelatihan tertentu sesuai dengan tuntutan pekerjaan tersebut.

Individu ketika memasuki perguruan tinggi yaitu usia 18-24 tahun, berada pada tahap eksplorasi (Sharf, 2006, p. 75), dimana individu mencoba berbagai macam hal dengan tujuan untuk mengklarifikasi karier apa yang sebenarnya mereka inginkan, mulai menspesifikan karier yang akan diraih sesuai dengan minat mereka dan mulai membuat rencana secara lebih objektif dan konkrit berkaitan dengan tujuan yang akan mereka capai dan sudah mulai terjadi proses pencarian kerja yang tetap. Banyak remaja yang gagal untuk mengintegrasikan minat, keterampilan, bakat dan tidak dapat fokus ke arah tujuan kariernya yang utama, padahal ini adalah tugas utama dari tahap eksplorasi.

Perguruan tinggi memiliki peran yang penting untuk mempersiapkan sumber daya yang berkualitas dan berorientasi masa depan yang lebih matang dari jenjang sebelumnya. Artinya diharapkan perguruan tinggi mampu mencetak tenaga-tenaga terampil berkualitas yang mampu mengembangkan ilmu yang dimiliki dan dapat diaplikasi dalam pekerjaan atau profesi yang ditekuninya kelak (Nurmi, 2011, p. 18). Karena alasan itulah, maka mahasiswa perlu memahami mengenai proses persiapan terhadap pilihan karier, yaitu memasuki dunia kerja sesuai dengan kemampuan dan bidang keahliannya.

Hasil penelitian yang dilakukan oleh sebuah lembaga konsultasi psikologi di Bandung yang mengadakan pelatihan dengan tema "Strategi Menembus Dunia Kerja" (Anggraini, 2012, p. 34). Kepada para peserta pelatihan tersebut diberikan angket mengenai berbagai bidang pekerjaan yang sesuai dengan latar belakang pendidikannya. Dari angket tersebut ditemukan bahwa para calon sarjana baru tersebut kurang mengetahui dan memahami berbagai altenatif pekerjaan yang sesuai dengan latar belakang pendidikannya serta lebih banyak memilih pekerjaan-pekerjaan yang berbeda dengan pendidikan yang ditempuh.

Bimbingan karier di semua jenjang pendidikan, termasuk perguruan tinggi merupakan salah satu strategi penting untuk membantu konseli menghadapi transisi ke dunia kerja. Intervensi pengembangan karier yang efektif harus dimulai sejak dini dan secara kontinyu terus dikembangkan sampai masa dewasa. Upaya-upaya untuk mengintervensi proses karier sepanjang rentang kehidupan dapat mempercepat atau memperkuat penemuan pengetahuan, sikap-sikap, dan keterampilan-keterampilan tentang diri (self) dan dunia kerja (world of work). Melalui strategi layanan bimbingan karier, mahasiswa harus dipersiapkan untuk mengatasi perubahan employment trends dengan dibekali kemampuan kreativitas, fleksibilitas, dan adaptabilitas di tengah-tengah kehidupan yang penuh dengan kompleksitas dan ambiguitas. Dalam konteks ini, konseli harus dibekali kemampuan membuat keputusan karier secara cepat, tepat, dan efektif dengan terlebih dahulu memantapkan orientasi kariernya.

Mempertimbangkan bimbingan karier bagi mahasiswa, terutama kematangan karier mahasiswa dibiarkan begitu saja, berlalu, dan berjalan dengan sendirinya. Maka mahasiswa akan mengalami kebingungan dan ketidaksiapan dalam mengahadapi tuntutan karier selanjutnya. Mahasiswa merupakan status akhir sebagai peserta didik sebelum memasuki dunia kerja dan tuntutan karier selanjutnya, sehingga mereka membutuhkan arahan, bimbingan karier untuk menstimulasi perkembangan dan pemantapan orientasi karier mereka secara optimal sesuai tingkat dan karakteristik khas perkembangan yang dilaluinya. Memahami bimbingan karier bagi mahasiswa, maka seorang dosen pembimbing akademik perlu, bahkan wajib memiliki kompetensi dalam 
memberikan layanan bimbingan karier dan menyediakan informasi karier yang up-todate, kreatif, inovatif, interaktif, dan mudah diakses.

\section{Konsep Dasar Bimbingan Karier}

Pemahaman terhadap istilah bimbingan karier tidak terlepas dari pemahamam berkenaan dengan karier. Dalam kehidupan sosial kemasyarakatan, berbagai istilah yang berkeanaan dengan karier dan pekerjaan seringkali dicampuradukkan. Pekerjaan mengandung arti sebagai aktivitas yang dilakukan oleh individu untuk memenuhi kebutuhan hidupnya secara ekonomis, dapat berubah-ubah seiring waktu berjalan dikarenakan adanya kemungkinan ketidakcocokan. Lebih lanjut, karier didefinisikan lebih luas dari pada hanya memenuhi kebutuhan ekonomis semata akan tetapi lebih dari rangkaian aktivitas yang dilakukan individu sepanjang rentang kehidupannya yang diyakini sebagai panggilan hidup serta mewarnai seluruh gaya hidupnya, Isaacson \& Brown (dalam Afdal 2015, p. 76). Sebagai suatu aktivitas yang nyata, karier memerlukan berbagai persiapan dan perencanaan yang matang sehingga membantu individu mencapai kesuksesan dan kemandirian untuk perkembangan yang optimal. Dalam pelayanan di perguruan tinggi hal-hal yang berkenaan dengan karier (termasuk dalamnya pekerjaan) diberikan melalui bimbingan karier.

Bimbingan karier merupakan salah satu upaya pendidikan yang membantu individu untuk mencapai kompetensi yang diperlukan dalam menghadapi masalahmasalah karier.Bimbingan karier merupakan bagian yang tak terpisahkan dari bimbingan dan konseling komprehensif yang pada awalnya disebut sebagai bimbingan jabatan. Dalam perkembangannya bimbingan jabatan telah diperluas menjadi bimbingan karier yang tidak hanya menekankan pelayanan pada keselarasan ciri diri individu dengan tuntutan jabatan atau pekerjaan, melainkan juga ditekankan pada proses pemilihan dan pengambilan keputusan karier dalam perjalanan hidup siswa (Surya, 2012, p. 63). Selain bimbingan karier, dikenal pula istilah konseling karier.

Pengertian bimbingan karier banyak ditemukan oleh para ahli, diantaranya yang dikemukakan Houghes (dalam Afdal 2015, p. 84). yang menyatakan bahwa bimbingan karier merupakan kegiatan yang dilaksanakan oleh konselor untuk mendorong dan memberikan faislitas perkembangan karier individu dalam seluruh kehidupan.Kegiatan bimbingan karier berhubungan dengan perencanaan pengambilan keputusan dan penyesuaian karier individu. Sedangkan Winkel (1997, p. 38), mengemukakan bimbingan karier adalah bimbingan dalam memilih pekerjaan dan mempersiapkan diri untuk memasuki serta menyesuaikan diri dengan berbagai tuntutan jenis pekerjaan tertentu.

Herr dan Cramer (1984, p. 6) memberikan pengertian bimbingan karier sebagai "The process of helping a person to develop and accept an integrated and adequate picture of himself and of his role in the world of work to test this concept again reality, and to convert it into a reality, with satisfaction to himself and to society". Pengertian yang diberikan mengandung arti bahwa ada dua hal penting yang terkendung dalam makna bimbingan karier, yaitu proses membantu individu untuk memahami diri, menerima diri sendiri sekaligus menyesuaikan diri dengan dunia kerja.

Berdasarkan beberapa pengertian di atas, dapat disimpulkan bahwa bimbingan karier merupakan bantuan yang diberikan kepada mahasiswa untuk menemukan dan mempersiapkan dirinya agar mampu merencanakan karier dan mengambil keputusan yang tepat sesaui dengan potensinya untuk kehidupan yang lebih baik di masa akan datang sesuai dengan tuntutan perkembangan ilmu pengetahuan dan teknologi. 


\section{Tujuan Bimbingan Karier}

Bimbingan karier secara umum bertujuan untuk membantu individu memperoleh kompetensi yang diperlukan agar bisa menentukan perjalanan hidupnya dan mengembangkan karier yang dipilihnya secara optimal.

Tujuan bimbingan karier secara lebih khusus telah digariskan oleh Asosiasi Bimbingan dan Konseling Indonesia (ABKIN, 2007) dalam rambu-rambu penyelenggaraan bimbingan dan konseling dalam jalur pendidikan formal, khsusunya tujuan layanan yang terkait dengan aspek karier yaitu:

1) Memiliki pemahaman diri berkenaan dengan kemampuan, minat dan kepribadian yang terhubung dengan pekerjaan;

2) Memiliki pengetahuan mengenai dunia kerja dan informasi karier yang menunjang kematangan kompetensi karier;

3) Memiliki sikap positif terhadap dunia kerja. Dalam arti mau bekerja dalam bidang pekerjaan apapun, tanpa merasa rendah diri, asal bermakna bagi dirinya dan sesuai dengan norma agama;

4) Memahami relevansi kompetensi belajar berupa kemampuan menguasai pelajaran dengan persyaratan keahlian atau keterampilan bidang pekerjaan yang menjadi citacita kariernya di masa depan;

5) Memiliki kemampuan untuk membentuk identitas karier, dengan cara mengenali ciriciri pekerjaan, kemampuan (persyaratan) yang dituntut, lingkungan sosio-psikologis pekerjaan, prospek kerja dan kesejahteraan kerja;

6) Memiliki kemampuan merencanakan masa depan, yaitu merancang kehidupan secara rasional untuk memperoleh peran tertentu yang sesuai dengan minat, kemampuan dan kondisi kehidupan sosial ekonomi;

7) Dapat membantu beberapa pola karier, yaitu kecenderungan arah karier, apabila seorang mahasiswa bercita-cita menjadi seorang dosen, amak senantiasa harus mengarahkan dirinya kepada sejumlah kegiatan yang relevan dengan karier tersebut;

8) Mengenal keterampilan, kemampuan dan minat. Keberhasilan atau kenyamanan dalam suatu karier amat dipengeruhi oleh kemampuan dan minat yang dimiliki. Oleh karena itu, maka setiap orang perlu memahami kemampuan dan minatnya, dalam bidang pekerjaan apa dia mampu, dan apakah dia berminat terhadap pekerjaan tersebut;

9) Memiliki kemampuan atau kematanagan untuk mengambil keputusan karier. (Depdiknas \& UPT LBK UPI, 2008, pp. 199-200)

\section{Kematangan Karier Mahasiswa}

Pemaknaan karier terbagi menjadi dua kelompok. Pertama, definisi kematangan karier yang menekankan tahapan hidup (life stage). Crites (Herr \& Cramer, 1979, p. 174; Riyadi, 2006) misalnya, mengatakan "...the maturity of an individual's vocational behavior as indicated by the similarity between his behavior and that of the oldest individuals in his vocational stages". Kematangan karier dianggap sebagai kongruensi (kesesuaian) antara perilaku karier individu dengan perilaku karier yang diharapkan pada usia tertentu di setiap tahap (Super dalam Ilfiandra, 1997: 52). Batasan ini ditambah dengan kutipan lain dari Super (Dillard, 1985, p. 22; Riyadi, 2006) yang menyatakan kematangan karier sebagai 
"...accomplishment of career developmental steps as compared with other individuals of the same age". Secara umum definisi kematangan karier yang dinyatakan Super pada pendefinisian kelompok pertama ini berujung pada "...the successful accomplishment of age and stage developmental tasks across the life span" (Jones, 2010, p. 101). Definisi ini memungkinkan orang mengartikan bahwa setiap tahap perkembangan karier yang dilewati individu akan melalui proses kematangan karier, termasuk usia anak-anak yang berada pada level pertumbuhan (growth).

Kedua, definsi yang menyatakan bahwa kematangan karier sebagai "...the readiness to make appropriate career decisions" (Super, 1980). Konsep ini muncul sebagai hasil dari penelitian ekstensif yang dilakukan Super dengan beberapa koleganya terhadap para remaja (Patton \& Lokan, 2001, pp. 32-33). Mereka memusatkan perhatiannya pada "... readiness to make (a) good choice(s)" atau kesiapan individu untuk membuat pilihan yang tepat (Sharf, 1992, p. 155; Savickas, 2001, p. 51; Riyadi, 2006).

Super sebagaimana diterjemahkan Manrihu (1986, pp. 32-34) memperjelas definisidefinisi tersebut dengan membedakan antaran Vocational Maturity I (Career Maturity/CM I) dan Vocational Maturity II (Career Maturity/ CM II). CM I didefinisikan sebagai tahap kehidupan di mana individu sebagaimana adanya ditunjukkan oleh tugas-tugas perkembangan yang ia hadapi berhubungan dengan tahap kehidupan di mana ia diharapkan menjadi demikian berdasarkan umurnya. Definisi CM II menyatakan kematangan perilaku dalam tahap kehidupan sesungguhnya (dengan tidak memandang apakah itu tahap yang diharapk an), seperti ditunjukkan oleh perilaku yang terlihat dalam hubungannya dengan tugas-tugas perkembangan dari tahap kehidupan sebenarnya dibandingkan dengan perilaku individu-individu lainnya yang menghadapi tugas-tugas perkembangan yang sama. Intinya, definisi CM II tidak menekankan pencapaian tugastugas berdasarkan usia, namun lebih menekankan unsur "kesiapan" personal yang dimiliki individu untuk memenuhi tugas perkembangan karier dari tahap eksplorasi hingga tahap deklinasi. Artinya, batasan tersebut menekankan kematangan karier akan dilalui mulai dari saat individu berada pada tahap remaja yaitu pada tahap eksplorasi karier hingga tahap kemunduran.

Career Maturity Inventory (CMI), yang dikonstruksi oleh Crites terdiri dari dua bagian, yang masing-masing menilai dimensi-dimensi kematangan karier yang berbeda, yaitu sikap dan kompetensi,. Dimensi sikap, terdiri atas: (1) keterlibatan, mengukur kecenderungan arah tindakan individu terhadap pemilihan karier, kecenderungan yang dimanifestasikan dalam keterlibatan atau keikutsertaan dalam proses pengambilan keputusan karier, (2) kemandirian, ketidakbergantungan pada pihak lain, terutama orang tua dalam proses pengambilan keputusan karier, (3) orientasi, cara pandang individu dalm proses pengambilan keputusan karier, (4) kompromi, adanya keluwesan atau kerelaan invidu untuk menerima usulan/saran dari pihak laindalam kaitannya dengan proses pengambilan keputusan karier, dan (5) penentuan keputusan, adanya ketegasan/keajegan/kepastian dalam proses pengambilan keputusan karier. Dimensi kompetensi, terdiri atas: (1) pemahaman diri, yaitu penguasaan terhadap kelebihan dan kekurangan diri sendiri, (2) informasi pekerjaan, penguasaan terhadap syarat-syarat pekerjaan, pendidikan/pelatihan pekerjaan dan pengetahuan praktis tentang pekerjaan, (3) pemilihan pekerjaan, penguasaan terhadap seleksi tujuan dan nilai-nilai pribadi yang dikejar dalam suatu pekerjaan, (4) perencanaan pekerjaan, penguasaan terhadap langkahlangkah yang logis dan sistematis dalam proses merencanakan dan mengambil keputusan karier, dan (5) pemecahan masalah, penguasaan terhadap cara-cara/strategi dalam menyelesaikan persoalan yang dihadapi dalam proses pengambilan keputusan karier 
Berdasarkan uraian dari beberapa batasan kematangan karier di atas, mungkin kedua pengertian tersebut benar bagian dari pernyataan Super tentang kematangan karier. Namun, definisi konseptual kematangan karier untuk kepentingan studi ini dijatuhkan pada penjelasan kematangan karier kelompok ke dua yang menyatakan kematangan karier sebagai kesiapan individu dalam membuat keputusan-keputusan karier yang tepat (Riyadi, 2006). Dari keadaan itu, konstruk beserta dimensi-dimensi yang membangunnya sangat detail dan jelas (Sharf, 1992; Patton \& Lokan, 2001; Riyadi, 2006). Selain itu, makna kematangan karier kelompok kedua ini sesuai dengan pendapat Hurlock (1980). yang mengatakan bahwa istilah "kematangan" merujuk pada kesiapan fungsi-fungsi individu untuk melakukan tugas perkembangan "belajar" untuk memperoleh pengalaman, sehingga dengan begitu individu dapat berkembang. Berdasarkan pernyataan Hurlock tersebut jelas sekali bahwa inti dari istilah kematangan adalah adanya "kesiapan".

Secara keseluruhan, konsep kematangan karier dalam konteks developmental digunakan untuk menunjukkan tingkat perkembangan karier, yaitu tahap yang dicapai pada kontinum perkembangan karier dari tahap eksplorasi sampai dengan tahap kemunduran (Super, 1957; Tennyson et. al, 1974; Manrihu, 1986, p. 32; Riyadi, 2006). Apabila dihubungkan dengan konsep Super (Sharf, 1992, pp. 190-191) tentang istilah recycling, maka pernyataan di atas dapat dimaknai bahwa individu bisa saja mengalami beberapa kali kematangan karier, terutama jika individu yang bersangkutan mengalami proses "daur ulang" (setelah melewati tahap kemunduran, kembali lagi memulai perkembangan kariernya dari mulai tahap eksplorasi dan seterusnya).

Konstruk kematangan karier Super dapat dipelajari dari inventori yang telah dikembangkan dengan para koleganya yakni inventori perkembangan karier (Career Development Inventory/CDI). Dalam CDI terdapat lima aspek pokok kematangan karier, yaitu perencanaan karier (career planning), eksplorasi karier (career exploration), pengetahuan tentang membuat keputusan (decision making), informasi (sejumlah pengetahuan) tentang dunia kerja (world-of-work information), dan pengetahuan tentang kelompok pekerjaan yang lebih disukai (knowledge of the preferred occupational group) (Sharf, 1992, pp. 155-159; Patton \& Lokan, 2001, pp. 33-34; Riyadi, 2006). Kemudian, aspek terakhir dalam kematangan karier Super yang tidak ada dalam CDI adalah realisme keputusan karier (realism) (Sharf, 1992, p. 155; Riyadi, 2006). Dengan demikian, konsep kematangan karier Super dibangun oleh enam aspek, termasuk realisme.

Pada pembahasan berikutnya, mahasiswa diidentifikasi berada pada tahap eksplorasi karier. Khususnya pada sub transisi (18-21 tahun), yang ditandai dengan menonjolnya pertimbangan yang lebih realistis untuk memasuki dunia kerja atau latihan profesional serta berusaha mengimplementasikan konsep dirinya. Kemudian sub "mencoba" (trial), dengan sedikit komitmen (22-24 tahun), ditandai dengan mulai ditemukannya lahan atau lapangan pekerjaan yang dipandang cocok, serta mencobanya sebagai sesuatu yang sangat potensial.

\section{METODE}

Penelitian ini menggunakan metode kuantitatif yang digunakan untuk menganalisis perbedaan profil kematangan karier mahasiswa STAI Siliwangi Bandung sebelum dan sesudah dilakukan perlakuan berupa intervensi melalui penafsiran secara statistik. Pendekatan yang digunakan adalah eksperimen quasi dengan desain penelitian nonequivalent pretest-posttest control group design (pretest-posttest dua kelompok). Penelitian 
eksperimen quasi dapat diartikan sebagai penelitian yang mendekati eksperimen atau eksperimen semu, dan merupakan penelitian yang dilakukan melalui uji coba untuk mengontrol atau memanipulasi variabel yang relevan.

\section{HASIL DAN PEMBAHASAN}

\section{Profil Kematangan Karier Mahasiswa STAI Siliwangi Bandung}

Hasil penelitian menunjukkan kematangan karier mahasiswa STAI Siliwangi Bandung tahun akademik 2016/2017 mencapai 53,52\% berada pada kategori kurang matang (sedang), sebesar 37,48\% berada pada kategori matang (tinggi) dan $9 \%$ berada pada kategori tidak matang (rendah). Secara lebih rinci gambaran kematangan karier mahasiswa disampaikan dalam tabel berikut.

Tabel 1. Gambaran Kematangan Karier Mahasiswa Tingkat STAI Siliwangi Bandung

\begin{tabular}{lc}
\hline Kriteria & Persentase \\
\hline Matang & 37,48 \\
\hline Sedang & 53,52 \\
\hline Tidak Matang & 9,00 \\
\hline Jumlah & 100 \\
\hline
\end{tabular}

Gambaran Kematangan Karier Mahasiswa Per-Aspek

Pada aspek sikap terhadap pilihan karier dalam bidang profesi kependidikan dua indikator berada pada kategori tinggi yaitu: indikator orientasi sebesar $88,45 \%$. Indikator keterlibatan sebesar $47,94 \%$, indikator kemampuan untuk bekerjasama/kompromi sebesar $49,18 \%$, dan indikator penentuan keputusan sebesar 45,05\% berada pada kategori sedang dan indikator kemandirian, sebesar 6,91\% berada pada kategori rendah.

Tabel 2. Gambaran Kematangan Karier Aspek Sikap

\begin{tabular}{lllc}
\hline Sikap & Indikator & Kategori & Persentase \\
\hline 1 & Keterlibatan & Sedang & 47,94 \\
\hline 2 & Kemandirian & Rendah & 6,91 \\
\hline 3 & Orientasi & Tinggi & 88,45 \\
\hline 4 & Kompromi & Sedang & 49,18 \\
\hline 5 & Penentuan keputusan & Sedang & 45,05 \\
\hline
\end{tabular}

Pada aspek Kompetensi karier mahasiswa dalam memilih karier pada bidang profesi kependidikan menggambarkan kategori tinggi. Indikator pemahaman diri, sebesar $85,36 \%$, serta penguasaan informasi pekerjaaan sebesar $55,57 \%$, dan indikator pemilihan pekerjaan berada pada kategori sedang sebesar $43,30 \%$, serta indikator perencanaan pekerjaan sebesar $11,75 \%$, dan indikator pemecahan masalah $14,85 \%$ berada pada kategori rendah.

Tabel 3. Gambaran Kematangan Karier Mahasiswa Aspek Kompetensi

\begin{tabular}{cllc}
\hline Kompetensi & Indikator & Kategori & Persentase \\
\hline 1 & Pemahaman diri & Tinggi & 85,36 \\
\hline 2 & Informasi pekerjaan & Sedang & 55,57 \\
\hline 3 & Pemilihan pekerjaan & Sedang & 43,30 \\
\hline 4 & Perencanaan pekerjaan & Rendah & 11,75 \\
\hline 5 & Pemecahan masalah & Rendah & 14,85 \\
\hline
\end{tabular}


Secara umum mahasiswa berada pada kategori sedang atau kurang matang dalam kariernya. Hal tersebut ditunjukkan dengan sikap yang ragu-ragu terhadap pekerjaan dalam bidang profesi kependidikan dan belum mampu menguasai pemilihan pekerjaan dalam bidang profesi kependidikan.

\section{Hasil Uji Efektifitas}

Hasil uji efektifitas kematangan karier mahasiswa menunjukkan bahwa model bimbingan karier kolaboratif yang diimplementasikan mampu meningkatkan kematangan karier mahasiswa. Keefektifan penelitian ini tentunya tidak datang secara tiba-tiba melainkan melalui proses penilitian. Keberhasilan penelitian ini didukung oleh adanya studi kebutuhan (need assesment) terhadap kebutuhan siswa dalam mematangkan kariernya. Melalui studi pendahuluan yang sudah dilakukan, dosen memahami bahwa kegiatan bimbingan bukanlah kegiatan insidentil semata, yang hanya dilaksanakan jika mahasiswa menghadapi masalah, akan melakukan kajian tentang berbagai kebutuhan mahasiswa dan juga studi terhadap berbagai kebutuhan orangtua terhadap pendidikan anaknya.

Bimbingan karier ini secara efektif merubah kematangan karier mahasiswa ke arah yang lebih mantap, dikarenakan adanya evaluasi, baik dari mahasiswa, dosen maupun oleh orangtua itu sendiri. Evaluasi yang dimaksud dapat berupa evaluasi proses pelaksanaan rencana tindakan per minggu bagi dosen dan mahasiswa di perguruan tinggi dan evaluasi terhadap pengisian lembar kerja mahasiswa di rumah oleh orangtua. Evaluasi penting dilakukan oleh berbagai pihak dalam pelaksanaan bimbingan untuk melihat sejauh mana kualitas keberhasilan model bimbingan

Pada akhirnya, model ini dapat diterapkan untuk membantu mahasiswa mematangkan karier yang lebih mantap sebagai bagian dari bimbingan karier. Pelaksanaan model ini memenuhi harapan Jones (2010) yang mengharapkan hendaknya bimbingan karier membantu mahasiswa mengembangkan keterampilan pengambilan keputusan dan keterampilan lainnya yang diperlukan untuk sukses pada tahapan selanjutnya. Melalui bimbingan karier kolaboratif karier mahasiswa dibantu untuk mencapai potensi mereka sepenuhnya untuk menjadi pembelajar yang efektif, warga yang bertanggung jawab, dan produktif. Penelitian yang dilakukan oleh John juga menunjukkan bahwa keterlibatan orangtua dalam pendidikan anak khususnya melalui interaksi kampus seperti open house, pertemuan orangtua-dosen dan pameran karier memiliki hubungan yang positif dengan keberhasilan anak. Keterlibatan keluarga dalam proses perguruan tinggi lanjutan dan eksplorasi karier merupakan kontribusi penting bagi pembangunan pendidikan dan karier remaja yang positif. Hargrove, Creagh, dan Burgess (2002) melalui hasil penelitian lain juga menujukkan bahwa dosen professional hendaknya memanfaatkan advokasi dan keterampilan kepemimpinan yang akan berpengaruh positif pada kesuksesan mahasiswa.

\section{SIMPULAN}

Hasil penelitian menunjukkan bahwa setelah diberikan bimbingan karier kolaboratif sebagian besar mahasiswa STAI Siliwangi Bandung semester tujuh/tingkat empat tahun akademik 2016-2017 pada umumnya cenderung mencapai kematangan karier pada kategori sedang. Kondisi ini ditandai dengan adanya sikap positif terhadap pilihan kariernya dan memiliki kompetensi karier yang tinggi.

Secara umum diperoleh bukti empirik bahwa bimbingan karier efektif untuk untuk mengembangkan kematangan karier mahasiswa. Dengan kata lain hasil uji coba model 
menunjukkan bahwa ditinjau secara keseluruhan baik pada setiap aspek maupun indikator-indikatornya cenderung mengalami perubahan tingkat kematangan yang lebih berarti (signifikan) setelah menggunakan bimbingan karier, meskipun terdapat beberapa indikator yang menunjukkan secara tidak signifikan. Namun demikian model bimbingan karier kolaboratif ini, dapat memberikan kontribusi sebagai pendekatan yang efektif untuk mengembangkan kematangan karier mahasiswa STAI Siliwangi Bandung.

Penelitian ini baru dilakukan kepada para mahasiswa semester tujuh ke atas, padahal berdasarkan temuan menunjikkan bahwa kebutuhan akan informasi atau bimbingan tentang kematangan karier ini sudah mulai dirasakan oleh mahasiswa pada semester-semester awal. Berdasarkan alasan tersebut, maka bagi peneliti selanjutnya dapat memperluas subjek penelitiannya dengan melibatkan para mahasiswa pada semester-semester awal. Agar lebih menunjukkan hasil penelitian yang lebih komprehensif, sebaiknya subjek penelitian ini tidak hanya melibatkan mahasiswa STAI Siliwangi Bandung, tetapi melibatkan juga mahasiswa dari perguruan tinggi lain.

\section{REFERENSI}

Afdal. (2015). Model bimbingan karier kolaboratif dalam memantapkan perencanaan karier siswa $S M A$. (Unpublished doctoral's disertation) Universitas Pendidikan Indonesia, Bandung, Indonesia.

ABKIN. (2007). Penataan pendidikan profesional konselor dan layanan bimbingan dan konseling dalam jalur pendidikan formal. Bandung: Asosiasi Bimbingan dan Konseling Indonesia.

Anggraini, K. S. (2012). Gambaran kematangan karier pada mahasiswa yang meingikuti unit kegiatan mahasiswa di Universitas Sumatera Utara. Jurnal Psikologi Indonesia, $1(1), 23-28$.

Crites, J. O. (1981). Career counseling: Models, methods, and materials (Vol. 30, no 2). New York: McGraw-Hill Book Company.

Depdiknas, \& UPT LBK UPI. (2008). Panduan program pengembangan perencanaan karier mahasiswa IKIP Bandung. Depdiknas \& UPTLBK UPI.

Hargrove, B. K., Creagh, M. G., \& Burgess, B. L. (2002). Family interaction patterns as predictors of vocational identity and career decision-making self-efficacy. Journal of Vocational Behavior, 61(2), 185-201.

Santrock, John W. (2003). Perkembangan remaja, (Terj. Istiwidayanti dan Soejarwo). Jakarta: Erlangga.

Herr, E. L., \& Cramer, S. H. (1984). Career guidance and counseling through the life span, systematic approach. Boston: Little Brown.

Houghes, K. L., \& Karp, M. M. (2004). School based career development: A synthetic of the literature. institute on education and economy. Retrieved March 11, 2016, from http://www.tc.columbia.edu.

Hurlock, E. B. (1980). Psikologi perkembangan. suatu pendekatan sepanjang rentang kehidupan (terj. Istiwidayanti dan Soedjarwo). Jakarta: Erlangga. 
Ilfiandra. (1997). Kontribusi konsep diri terhadap kematangan karier siswa. (Unpublished bachelor's thesis) Universitas Pendidikan Indonesia, Bandung, Indonesia.

Isaacson, L. E., \& Brown, D. (1997). Career information, career counseling and career development ( $\left.A P A 6^{\text {th }} e d\right)$. Boston: Allyn and Bacon.

Jones, V. R. (2010). Virginia's Academic and career plan emphasizes middle school. Techniques: Connecting Education and Careers (J1), 85(7), 24-27.

Manrihu, M. T. (1986). Studi tentang beberapa faktor yang mempengaruhi kematangan karier siswa SMA di Sulawesi Selatan. (Unpublished doctoral's disertation) Universitas Pendidikan Indonesia, Bandung, Indonesia.

Manrihu, M. T. (1992). Pengantar bimbingan dan konseling karier. Jakarta: Bumi Aksara.

Nurmi, J. E. (2011). Future orientation. Helsinki: University of Helsinki.

Patton, W., \& Lokan, J. (2001). Perspectives on Donald Super's construct of career maturity. International Journal for Educational and Vocational Guidance, 1(1-2), 31-48.

Riyadi, A.R. (2006). Pengembangan alat ukur kematangan karier siswa sekolah menengah atas. (Unpublished bachelor's thesis) Universitas Pendidikan Indonesia, Bandung, Indonesia.

Savickas, M. L. (2001). A developmental perspective on vocational behaviour: Career patterns, salience, and themes. International Journal for Educational and Vocational Guidance, 1(1-2), 49-57.

Sharf, R.S. (1992). Applying career development theory to counseling. California: Woodswoth, Inc.

Sharf, R. S. (2006). Applying carrer development theory to counseling ( $4^{\text {th }}$ ed.). California: Thomson Wadsworth.

Sharf, R. S. (2010). Applying career development theory to counseling (Fifth edition). CA USA: Brooks/Cole Cencage Learning.

Super, D. E. (1980). A life-span, life-space approach to career development. Journal of Vocational Behavior, 16(3), 282-298.

Super. D. E., \& Bowlsbey. J. H. (1979). Golden career exploration. New York: Psychological Corporation.

Surya, M. (2012). Bimbingan karier berbasis nilai-nilai keluarga. Makalah. Keynote Speaker dalam Seminar dan Lokakarya Nasional Bimbingan Karier diselenggarakan oleh Sekolah Pasca Sarjana UPI Bandung bekerja sama dengan MGBK Kabupaten Bandung, bertempat di SMK Negeri 2 Baleendah Kabupaten Bandung, tanggal 27 November 2012.

Tennyson, W. W., Miller, G. D., Skovholt, T. M., \& Williams, R. C. (1989). How they view their role: A survey of counselors in different secondary schools. Journal of Counseling E Development, 67(7), 399-403.

Winkel, W. S. (1997). Bimbingan dan konseling di institusi pendidikan. Jakarta: Grasindo. 